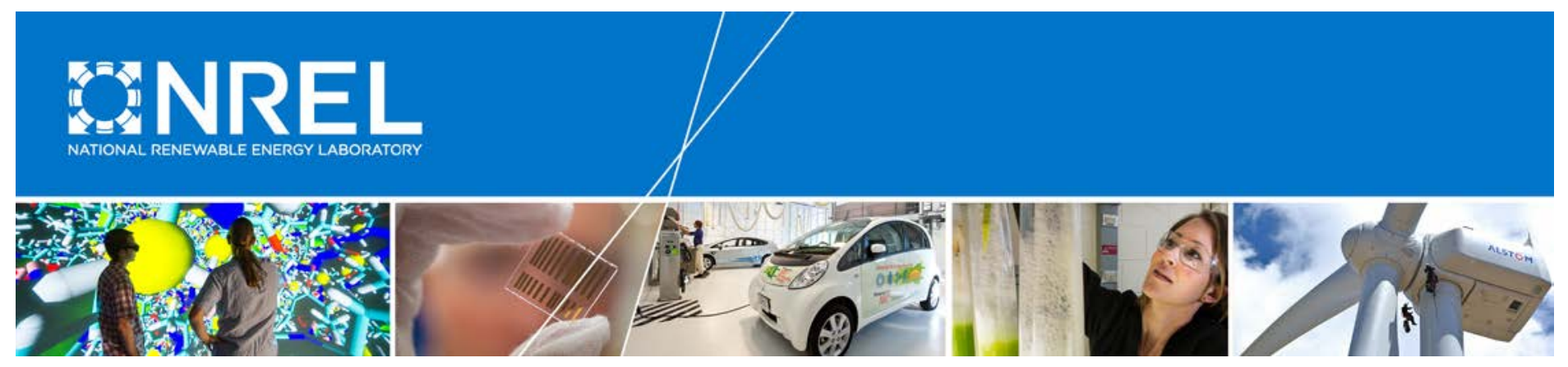

\title{
2016 Survey of Non-Starch Alcohol and Renewable Hydrocarbon Biofuels Producers
}

\author{
Ethan Warner and Amy Schwab \\ National Renewable Energy Laboratory \\ Dina Bacovsky \\ Bioenergy 2020+ GmbH
}

NREL is a national laboratory of the U.S. Department of Energy Office of Energy Efficiency \& Renewable Energy Operated by the Alliance for Sustainable Energy, LLC

This report is available at no cost from the National Renewable Energy Laboratory (NREL) at www.nrel.gov/publications.

Technical Report

NREL/TP-6A10-67539

February 2017

Contract No. DE-AC36-08G028308 


\title{
2016 Survey of Non-Starch Alcohol and Renewable Hydrocarbon Biofuels Producers
}

\author{
Ethan Warner and Amy Schwab \\ National Renewable Energy Laboratory \\ Dina Bacovsky \\ Bioenergy $2020+\mathrm{GmbH}$
}

Prepared under Task No. BZ14.3008

NREL is a national laboratory of the U.S. Department of Energy Office of Energy Efficiency \& Renewable Energy Operated by the Alliance for Sustainable Energy, LLC

This report is available at no cost from the National Renewable Energy Laboratory (NREL) at www.nrel.gov/publications.

National Renewable Energy Laboratory 15013 Denver West Parkway Golden, CO 80401

303-275-3000 • www.nrel.gov

\section{Technical Report}

NREL/TP-6A10-67539

February 2017

Contract No. DE-AC36-08G028308 


\section{NOTICE}

This report was prepared as an account of work sponsored by an agency of the United States government. Neither the United States government nor any agency thereof, nor any of their employees, makes any warranty, express or implied, or assumes any legal liability or responsibility for the accuracy, completeness, or usefulness of any information, apparatus, product, or process disclosed, or represents that its use would not infringe privately owned rights. Reference herein to any specific commercial product, process, or service by trade name, trademark, manufacturer, or otherwise does not necessarily constitute or imply its endorsement, recommendation, or favoring by the United States government or any agency thereof. The views and opinions of authors expressed herein do not necessarily state or reflect those of the United States government or any agency thereof.

This report is available at no cost from the National Renewable Energy Laboratory (NREL) at www.nrel.gov/publications.

Available electronically at SciTech Connect http:/www.osti.gov/scitech

Available for a processing fee to U.S. Department of Energy and its contractors, in paper, from:

U.S. Department of Energy

Office of Scientific and Technical Information

P.O. Box 62

Oak Ridge, TN 37831-0062

OSTI http://www.osti.gov

Phone: 865.576.8401

Fax: 865.576.5728

Email: reports@osti.gov

Available for sale to the public, in paper, from:

U.S. Department of Commerce

National Technical Information Service

5301 Shawnee Road

Alexandria, VA 22312

NTIS http://www.ntis.gov

Phone: 800.553 .6847 or 703.605 .6000

Fax: 703.605.6900

Email: orders@ntis.gov 


\section{List of Acronyms}

$\mathrm{A} / \mathrm{E}$

$\mathrm{BC}$

FOG

$\mathrm{HC}$

IEA

MMGY

MSW

NREL

TC acid or enzymatic

biochemical

fats, oils, and greases

hydrocarbons

International Energy Agency

million gallons per year

municipal solid waste

National Renewable Energy Laboratory

thermochemical 


\section{Executive Summary}

To understand the status of the industry for non-starch alcohol and renewable hydrocarbon biofuels as of the end of calendar year 2016, the National Renewable Energy Laboratory (NREL) updated its annual survey of biofuel projects. This report presents the results of this survey, describes the survey and data collection methodology, and documents important changes to those methods since the 2015 survey (Schwab, Warner, and Lewis 2016). Historically this survey has focused solely on the U.S., but in this 2016 report, international commercial-scale biorefinery projects are now included to assess the current status of commercial technologies.

The survey and data collection methods used in this 2016 report also changed relative to the 2015 survey. We began identifying non-starch alcohol and renewable hydrocarbon projects based on publicly available data obtained directly from company websites, press releases, and public filings. If the biorefinery project was active, then representatives from the companies or knowledgeable industry experts were directly contacted for data collection. Representatives from these companies or industry experts were asked a standard set of questions. Topics in the questionnaire included stage of development of the facility and its scale, feedstock, and biofuel products, among other questions. Industry experts from NREL and the U.S. Department of Energy validated the U.S. responses and compared them with publicly available data and experts from the International Energy Agency (IEA) Bioenergy Task 39 network vetted international data. Due to the lack of available contacts, data on inactive projects (e.g., idled biorefineries) are often based on prior survey responses or publicly available data. Table ES-1 summarizes biorefinery project counts from this survey, organized by feedstock and technology categories. Ninety-eight U.S. pilot-, demonstration-, and commercial-scale biorefineries and 31 international commercial biorefineries were found with sufficient data for inclusion in this report.

Table ES-1. 2016 Survey of Biorefinery Projects by Technology and Feedstock Categories

\begin{tabular}{|c|c|c|c|c|}
\hline & \multicolumn{3}{|c|}{ U.S. Biorefineries } & \multirow{2}{*}{$\begin{array}{c}\text { International } \\
\text { Biorefineries } \\
\text { Commercial }\end{array}$} \\
\hline & Pilot & Demonstration & Commercial & \\
\hline Non-Starch Alcohol (BC) from Cellulose & $7(3)$ & $7(3)$ & $17(5)$ & II (6) \\
\hline Non-Starch Alcohol (TC) from Cellulose & $2(2)$ & 0 & $\mathrm{I}(0)$ & $2(1)$ \\
\hline Non-Starch Alcohol (TC/BC) from Cellulose & $\mathrm{I}(0)$ & 0 & $\mathrm{I}(0)$ & 0 \\
\hline Non-Starch Alcohol from Algae & $2(2)$ & I (I) & 0 & 0 \\
\hline Total Non-Starch Alcohols & $12(7)$ & $8(4)$ & $19(5)$ & $13(7)$ \\
\hline Renewable HC (TC) from Cellulose & $15(10)$ & $7(2)$ & $4(0)$ & I (0) \\
\hline Renewable HC (TC) from Fats, Oils, and Greases & I (I) & $2(1)$ & $9(4)$ & II (I0) \\
\hline Renewable HC (TC) from Algae & $5(1)$ & 0 & 0 & 0 \\
\hline Renewable HC (BC) from Cellulose & I (0) & $2(2)$ & 0 & 0 \\
\hline Total Renewable HC & $22(12)$ & I I (5) & $13(4)$ & $12(10)$ \\
\hline Cellulosic Sugars & $2(2)$ & $3(2)$ & 0 & 0 \\
\hline Oils (pyrolysis) & $3(2)$ & I (0) & I (0) & $5(3)$ \\
\hline Oils (algae) & I (I) & $\mathrm{I}(\mathrm{I})$ & 0 & $\mathrm{I}(\mathrm{I})$ \\
\hline Syngas (from pyrolysis) & I (I) & 0 & 0 & 0 \\
\hline Total Intermediate Products & $7(6)$ & $5(3)$ & I (0) & $6(4)$ \\
\hline Grand Total & $41(25)$ & $24(12)$ & $33(9)$ & 3 I (2I) \\
\hline
\end{tabular}

Operating projects are in $(. \mathrm{BC}=$ biochemical, $\mathrm{HC}=$ hydrocarbons, $\mathrm{TC}=$ thermochemical. 


\section{Table of Contents}

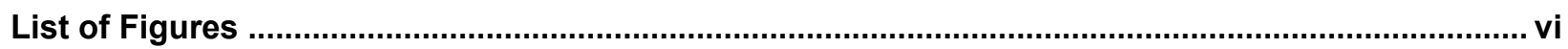

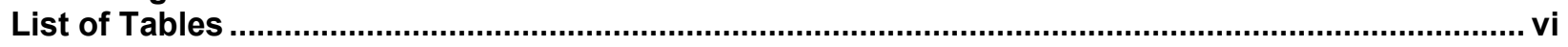

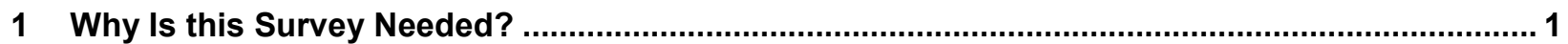

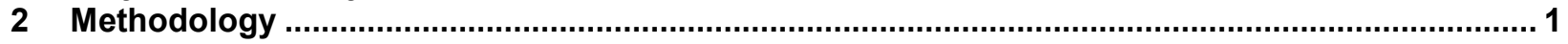

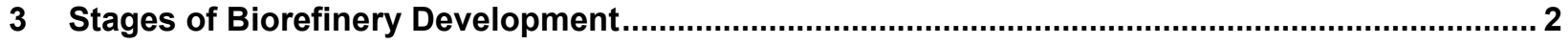

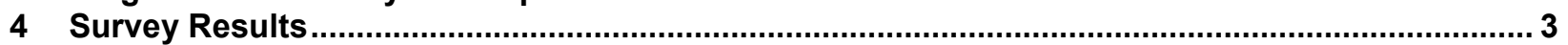

4.1 Status of Commercial Non-Starch Alcohol Biorefineries .......................................................... 3

4.2 Status of Pre-Commercial Non-Starch Alcohol Biorefineries in the U.S. .................................. 8

4.3 Status of Commercial Renewable Hydrocarbon Biorefineries ............................................... 10

4.4 Status of Pre-Commercial Renewable Hydrocarbon Biorefineries in the U.S........................... 15

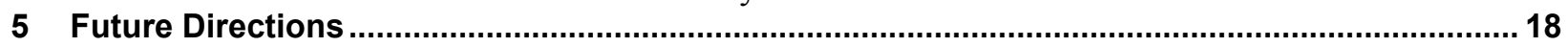

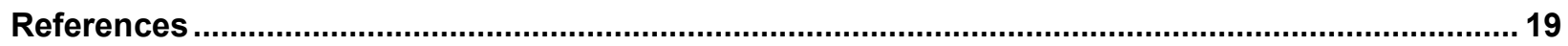

Appendix A: Definitions for Stage of Facility Development ...................................................... 23

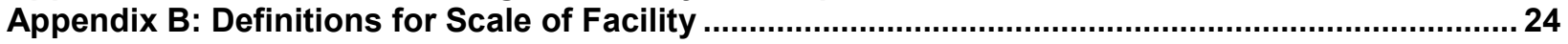

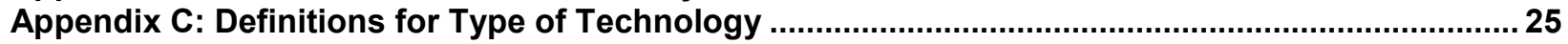

Appendix D: Definitions for Feedstock Category ........................................................................ 26

Appendix E: Definitions for Anticipated Product/Market.......................................................... 27 


\section{List of Figures}

Figure 1. Characteristics of commercial non-starch alcohol projects at the end of 2016

Figure 2. Characteristics of pilot- and demonstration-scale non-starch alcohol projects in the U.S. at the end of 2016.

Figure 3. Characteristics of U.S. and international commercial renewable hydrocarbon projects at the end of 2016

Figure 4. Characteristics of U.S. demonstration- and pilot-scale renewable hydrocarbon projects at the end of 2016

\section{List of Tables}

Table ES-1. 2016 Survey of Biorefinery Projects by Technology and Feedstock Categories....................iv

Table 1. 2016 Survey of Biorefinery Projects by Technology and Feedstock Categories............................ 3

Table 2. Commercial Non-Starch Alcohol Projects in 2016 by Technology and Feedstock Category ........ 4

Table 3. Pre-Commercial Non-Starch Alcohol Projects in 2016 by Technology and Feedstock Category 10

Table 4. Commercial Renewable Hydrocarbon Projects in 2016 by Technology and Feedstock Category 11

Table 5. U.S. Demonstration- and Pilot-Scale Renewable Hydrocarbon Projects in 2016 by Technology

and Feedstock Category 


\section{Why Is this Survey Needed?}

The published literature includes a number of biofuels industry data compilations, covering a range of products, technologies, countries, and timeframes (Hart Energy 2011; Bacovsky et al. 2013; Soleki et al. 2014; Lane 2013; British Petroleum 2016; PricewaterhouseCoopers LLP 2014; IEA 2016; USDA 2016; IEA 2014; IRENA 2016). In the past, extensive review and reconciliation across these differing sources was required to keep track industry progress by, for example, creating inputs to models tracking industry development (Peterson et al. 2013).

This survey report was established to provide a publicly available, open-source documentation of the status of the non-starch alcohol and renewable hydrocarbon ${ }^{1}$ biofuels industry in the United States as it existed at the end of 2016. This 2016 survey has been expanded to include non-U.S. commercial projects in order to provide a summary of the state of commercial biofuel technologies. The expansion of this report's scope is the outcome of collaboration on data collection and vetting with the International Energy Agency (IEA) Task 39 project "Second Generation Biofuel Demonstration Facilities," which is managed by Bioenergy2020+ GmbH (IEA 2016). Collaboration helped reduced duplicative data collection and vetting, and improved assessment of the commercial biofuel technologies.

\section{Methodology}

Besides international commercial projects, this survey methodology was also expanded to include data collection on projects producing products intermediate to fuel production, such as cellulosic sugars and pyrolysis oils and the addition of new conversion technologies to existing biorefineries based on the identification of growth in these types of projects in the 2015 survey. For the purposes of this survey, a "project" is considered to include a biorefinery, the expansion of existing biorefinery capacity, or the addition of new conversion technologies, such as for the conversion of corn kernel cellulose at corn ethanol dry mills.

Updates to the methodology used in the 2015 biorefinery survey (Schwab, Warner, and Lewis 2016) included more focused outreach to biorefinery projects. For U.S. projects, the original list of survey recipients from 2015 formed the basis of the initial 2016 survey of the U.S. project population. The initial U.S. project list was expanded based on searches of public data to include projects that were founded since the 2015 survey. The IEA Task 39 database of biofuel facilities was used for data on international commercial projects (IEA 2016). If a biorefinery project was active, then attempts were made to contact representatives from the companies or knowledgeable industry experts for the vetting of collected data. Due to the lack of available contacts and historic response rates, data on inactive projects (e.g., idled biorefineries) may be based on prior survey responses or publicly available data. Industry experts from the National Renewable Energy Laboratory (NREL) and the U.S. Department of Energy validated the U.S. responses and experts from the IEA Bioenergy Task 39 network vetted international data. The online survey methodology from the 2015 report can be found in Schwab, Warner, and Lewis (2016).

\footnotetext{
${ }^{1}$ Renewable hydrocarbons are fuels produced from biomass sources and are similar to petroleum gasoline, diesel, or jet fuel in chemical makeup and are therefore considered infrastructure-compatible fuels.
} 
Identified projects were screened to ensure that they fell within the defined scope of this study as a non-starch alcohol or renewable hydrocarbon biofuels producer planning, developing, owning, or operating (including operating, commissioning, and start-up) a pilot-, demonstration-, or commercial-scale (including pioneer- and full commercial-scale) biorefinery in the U.S. or a commercial project internationally. Projects that had been cancelled were eliminated from the dataset in this report. Pre-commercial (i.e., pilot- and demonstration-scale) facilities with those assets that had been sold off and are now defunct were also eliminated.

We collected information on 129 projects ( 98 in the U.S. and 31 internationally) operated by 87 companies. Twenty-seven of the companies operated multiple facilities in the U.S. or internationally. Three companies have facilities for which they are pursuing capacity expansions of the installed technology, and 11 companies are pursing the addition of new conversion technologies to an existing facility. Data for all projects were supplemented based on research of publicly available information. Data updates were compiled through early December 2016.

Requested or collected project details included company information, stage of development, facility scale, feedstock, technology, product, and more. Appendices A-E define the major categories used to organize project data used in this report: stage of development of facility, scale, technology type, feedstock, and anticipated product/market. The availability of precise data on biorefinery projects varied, so organizing categories should not be interpreted as providing a complete picture of an individual project. For example, companies typically employ a proprietary conversion process and there may be aspects of a company's process that incorporate elements of technologies other than the primary deconstruction and upgrading technologies indicated in Appendix C. Data from the 2015 survey in Schwab, Warner, and Lewis (2016) and IEA Task 39 was translated into this organizational framework.

\section{Stages of Biorefinery Development}

This report follows a staged development process and groups facilities into pilot-, demonstration-, and commercial-scale facilities as defined previously (DOE 2016). We reviewed the definition to be as specific as possible in its application to this report. We will continue to work with the Bioenergy Technologies Office to ensure that we are not excluding or including plants that respectively should or should not be included. Typically, a company will select an economically promising feedstock and technology pathway combination and move incrementally up the development scale chain in the following order (see Appendix B):

1. Pilot-scale: verifying the integrated technical performance of the selected suite of unit operations and conversion technologies.

2. Demonstration-scale: providing engineering and operating data and equipment specifications for the next development step.

3. Commercial-scale: proving economical production at commercial volumes on a continuous basis. "Commercial" includes pioneer and larger scale biorefineries.

Ultimately, each company will make its own individual choices regarding optimal feedstock throughput rates and scaling strategies for a particular facility, and some of these particular choices might not be fully represented by this report. However, this staged development process allows the project specifics to be vetted at increasing levels of process integration and size, while 
mitigating project risk and improving a company's confidence in its technology design prior to construction of a large commercial facility. As an expected part of the development process, smaller-scale facilities can eventually become idle (or be repurposed) as the project matures or once a facility has served its purpose and larger-scale facilities are built.

\section{Survey Results}

Table 1 summarizes projects in this 2016 survey by broad categories of feedstock and technology used (e.g., biochemical [BC] or thermochemical [TC]). Ninety-eight U.S. pilot-, demonstration-, and commercial-scale projects and 31 international commercial projects were found with sufficient data to be included in this report. For use in this survey report, we obtained and validated data from 39 U.S. non-starch alcohol projects, 46 U.S. renewable hydrocarbon projects, and 13 U.S. projects for producing intermediate products (e.g., cellulosic sugars and pyrolysis oil). We also obtained and validated international commercial data from 13 non-starch alcohol projects, 12 renewable hydrocarbon projects, and 6 projects for producing intermediate products.

Table 1. 2016 Survey of Biorefinery Projects by Technology and Feedstock Categories

\begin{tabular}{|c|c|c|c|c|}
\hline & \multicolumn{3}{|c|}{ U.S. Biorefineries } & \multirow{2}{*}{$\begin{array}{c}\text { International } \\
\text { Biorefineries } \\
\text { Commercial }\end{array}$} \\
\hline & Pilot & Demonstration & Commercial & \\
\hline Non-Starch Alcohol (BC) from Cellulose & $7(3)$ & $7(3)$ & $17(5)$ & II (6) \\
\hline Non-Starch Alcohol (TC) from Cellulose & $2(2)$ & 0 & $\mathrm{I}(0)$ & $2(1)$ \\
\hline Non-Starch Alcohol (TC/BC) from Cellulose & $\mathrm{I}(0)$ & 0 & $\mathrm{I}(0)$ & 0 \\
\hline Non-Starch Alcohol from Algae & $2(2)$ & $\mathrm{I}(\mathrm{I})$ & 0 & 0 \\
\hline Total Non-Starch Alcohols & $12(7)$ & $8(4)$ & $19(5)$ & I3 (7) \\
\hline Renewable HC (TC) from Cellulose & $15(10)$ & $7(2)$ & $4(0)$ & I (0) \\
\hline Renewable HC (TC) from Fats, Oils, and Greases & I (I) & $2(1)$ & $9(4)$ & II (I0) \\
\hline Renewable HC (TC) from Algae & $5(I)$ & 0 & 0 & 0 \\
\hline Renewable HC (BC) from Cellulose & I (0) & $2(2)$ & 0 & 0 \\
\hline Total Renewable HC & $22(12)$ & I I (5) & $13(4)$ & $12(10)$ \\
\hline Cellulosic Sugars & $2(2)$ & $3(2)$ & 0 & 0 \\
\hline Oils (pyrolysis) & $3(2)$ & I (0) & I (0) & $5(3)$ \\
\hline Oils (algae) & I (I) & $\mathrm{I}(\mathrm{I})$ & 0 & I (I) \\
\hline Syngas (from pyrolysis) & I (I) & 0 & 0 & 0 \\
\hline Total Intermediate Products & $7(6)$ & $5(3)$ & I (0) & $6(4)$ \\
\hline Grand Total & $41(25)$ & $24(12)$ & $33(9)$ & $3 I(2 I)$ \\
\hline
\end{tabular}

Operating projects are in $(\mathrm{l}) \mathrm{BC}=$ biochemical, $\mathrm{FOG}=$ fats, oils, and greases, $\mathrm{HC}=$ hydrocarbons, $\mathrm{TC}=$ thermochemical.

Of the U.S. commercial projects, $26 \%$ of the non-starch alcohol projects, $31 \%$ of the renewable hydrocarbon projects, and $0 \%$ of the intermediate product projects were operational (producing fuel or in commissioning) at the end of 2016. Of the commercial projects internationally, $54 \%$ of the non-starch alcohol projects, $75 \%$ of the renewable hydrocarbon projects, and $67 \%$ of the intermediate product projects were operational.

\subsection{Status of Commercial Non-Starch Alcohol Biorefineries}

Several U.S. projects began producing cellulosic alcohols during 2014-2016 that resulted in the assignment of D3 Renewable Identification Numbers (U.S. Environmental Protection Agency 
2016). About 0.73 million gallons of cellulosic alcohols were produced in 2014; about 2.2 million gallons of cellulosic alcohol were produced in 2015; and as of November 2016, about 3.3 million gallons of cellulosic ethanol were produced in that year. In 2016 about 85 million gallons per year (MMGY) of cellulosic ethanol production capacity exist. Figure 1 summarizes commercial non-starch alcohol projects identified during this survey.

Figure 1 summarizes commercial non-starch alcohol projects identified during this survey. Table 2 summarizes the U.S. and international commercial non-starch alcohol projects from this survey. Table 2 also summarizes the technology and feedstock categories used in each project. The majority of U.S. and international projects are using an acid or enzymatic (A/E) pretreatment and fermentation technology as well as using corn kernel cellulose or herbaceous (i.e., corn stover and dedicated energy crops) for $\mathrm{A} / \mathrm{E}$ pretreatment and fermentation projects.

Table 2. Commercial Non-Starch Alcohol Projects in 2016 by Technology and Feedstock Category

\begin{tabular}{|c|c|c|c|c|c|c|c|c|}
\hline \multicolumn{2}{|c|}{ Technology } & \multirow[t]{2}{*}{ Region } & \multirow{2}{*}{$\begin{array}{c}\text { Corn } \\
\text { Kernel } \\
\text { Cellulose }\end{array}$} & \multirow[t]{2}{*}{$\begin{array}{c}\text { Crop } \\
\text { Residues }\end{array}$} & \multirow{2}{*}{$\begin{array}{l}\text { Dedicated } \\
\text { Energy } \\
\text { Crops }\end{array}$} & \multirow[t]{2}{*}{ MSW } & \multirow[t]{2}{*}{$\begin{array}{l}\text { Woody } \\
\text { Biomass }\end{array}$} & \multirow[t]{2}{*}{ TOTAL } \\
\hline Deconstruction & Upgrading & & & & & & & \\
\hline $\begin{array}{c}\text { A/E } \\
\text { Pretreatment }\end{array}$ & Fermentation & U.S. & II (3) & $3(2)$ & I (0) & I (0) & I (0) & $17(5)$ \\
\hline Gasification & Syngas Catalytic & U.S. & & & & $I(0)$ & & I (0) \\
\hline Gasification & Fermentation & U.S. & & & & I (0) & & I (0) \\
\hline \multicolumn{3}{|c|}{ U.S. Total } & II (3) & $3(2)$ & I (0) & $3(0)$ & I (0) & $19(5)$ \\
\hline $\begin{array}{c}\text { A/E } \\
\text { Pretreatment }\end{array}$ & Fermentation & International & I (0) & $9(6)$ & I (0) & & & II (6) \\
\hline Gasification & Syngas Catalytic & International & & & & $2(1)$ & & $2(1)$ \\
\hline Gasification & Fermentation & International & & & & & & 0 \\
\hline \multicolumn{3}{|c|}{ International Total } & I (0) & $9(6)$ & I (0) & $2(1)$ & 0 & $13(7)$ \\
\hline & & Grand Total & $12(3)$ & $12(8)$ & $2(0)$ & $5(I)$ & I (0) & $32(12)$ \\
\hline
\end{tabular}

Operating projects are in ( ). A/E = acid or enzymatic, $M S W=$ municipal solid waste. 


\begin{tabular}{|c|c|c|c|c|c|c|c|c|c|c|}
\hline & $\begin{array}{c}\text { Deconstruction } \\
\text { Technology }\end{array}$ & $\begin{array}{l}\text { Upgrading } \\
\text { Technology }\end{array}$ & Project Name & Location Detail & $\begin{array}{l}\text { Anticipate } \\
\text { Product/ } \\
\text { Market }\end{array}$ & $\begin{array}{l}\text { Commercial } \\
\text { Capacity } \\
\text { (MMGY) }\end{array}$ & Operating & $\begin{array}{c}\text { Under } \\
\text { Construction }\end{array}$ & Planning & Idle \\
\hline \multirow{19}{*}{ כִ } & \multirow{17}{*}{$\begin{array}{c}\text { A/E } \\
\text { Pretreatment }\end{array}$} & \multirow{17}{*}{ Fermentation } & DuPont & Nevada, IA, USA & TBS & 30 & * & & & \\
\hline & & & Pacific Ethanol (EdeniQ) & Stockton, CA, USA & TBS & 1.5 & 4 & & & \\
\hline & & & POET-DSM & Emmetsburg, IA, USA & TBS & 20 & * & & & \\
\hline & & & Quad County Corn & Galva, IA, USA & TBS & 2.1 & 4 & & & \\
\hline & & & \multirow{4}{*}{ Flint Hills (EdeniQ) } & Shell Rock, IA, USA & TBS & 3 & 4 & & & \\
\hline & & & & Fairbank, IA, USA & TBS & 3 & & 4 & & \\
\hline & & & & lowa Falls, IA, USA & TBS & 2.5 & & 4 & & \\
\hline & & & & Menlo, IA, USA & TBS & 3 & & $\triangleleft$ & & \\
\hline & & & Redfield Energy (ICM) & Redfield, SD, USA & TBS & 3.42 & & 4 & & \\
\hline & & & E Energy Adams (ICM) & Adams, NE, USA & TBS & 3 & & 4 & & \\
\hline & & & Fiberight & Hampden, ME, USA & TBS & 6 & & $\diamond$ & & \\
\hline & & & Kansas Ethanol (ICM) & Lyons, KS, USA & - & 3.6 & & 4 & & \\
\hline & & & MAAPW (EdeniQ) & Madrid, NE, USA & TBS & 1.1 & & 4 & & \\
\hline & & & Siouxland Energy (EdeniQ) & Sioux Center, IA, USA & TBS & 1.5 & & 4 & & \\
\hline & & & Beta Renewables & Clinton, NC, USA & TBS & 20 & & & $\triangleright$ & \\
\hline & & & ZeaChem & Boardman, OR, USA & TBS/bioproducts & 22 & & & $\nabla$ & \\
\hline & & & Abengoa & Hugoton, KS, USA & TBS & 25 & & & & * \\
\hline & \multirow{2}{*}{ Gasification } & Syngas Catalytic & Enerkem & Pontotoc, MS, USA & TBS/bioproducts & 10 & & & $\diamond$ & \\
\hline & & Fermentation & INEOS New Planet Bioenergy & Vero Beach, FL, USA & TBS & 8 & & & & $\diamond$ \\
\hline \multirow{12}{*}{ 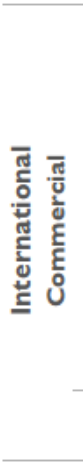 } & \multirow{10}{*}{$\begin{array}{c}\text { A/E } \\
\text { Pretreatment }\end{array}$} & \multirow{10}{*}{ Fermentation } & GranBio & Sao Miguel, Brazil & TBS & 22 & * & & & \\
\hline & & & Raizen Energia & Piracicaba, Brazil & TBS & 11 & * & & & \\
\hline & & & ShanDong Longlive & Yucheng, China & TBS & 20 & * & & & \\
\hline & & & \multirow{2}{*}{ Henan Tianguan Group } & Nanyang, China & TBS & $\begin{array}{l}10 \\
50\end{array}$ & $*$ & & * & \\
\hline & & & & Zhenping, China & TBS & 3.3 & * & & & \\
\hline & & & IGPC Ethanol & Alymer, Canada & - & 3.18 & & $\triangleleft$ & & \\
\hline & & & \multirow{3}{*}{ Beta Renewables } & Crescentino, Italy & TBS & 13 & * & & & \\
\hline & & & & Fujian, China & TBS & 30 & & & * & \\
\hline & & & & Strazske, Slovakia & TBS & 18 & & * & & \\
\hline & & & COFCO Zhaodong Co. & Zhaodong, China & TBS & 17 & & & $\triangleright$ & \\
\hline & \multirow{2}{*}{ Gasification } & \multirow{2}{*}{ Syngas Catalytic } & \multirow{2}{*}{ Enerkem } & Edmonton, Canada & TBS/bioproducts & 10 & $\diamond$ & & & \\
\hline & & & & Varennes, Canada & TBS/bioproducts & 10 & & & $\diamond$ & \\
\hline $\begin{array}{l}\text { Interm } \\
\text { Sugar } \\
\text { Synga }\end{array}$ & $\begin{array}{l}\text { ediate Product } \\
\text { rs } \\
\text { as }\end{array}$ & $\begin{array}{l}\text { Fee } \\
4 \\
*\end{array}$ & $\begin{array}{l}\text { dstock Category } \\
\text { torn Kernel Cellulose } \\
\text { rop Residues }\end{array}$ & $\begin{array}{l}\text { icated Energy Crops } \\
V\end{array}$ & Woody Biomass & & & & & \\
\hline
\end{tabular}

Figure 1. Characteristics of commercial non-starch alcohol projects at the end of 2016

$\mathrm{A} / \mathrm{E}=$ acid/enzymatic, $\mathrm{MMGY}=$ million gallons per year, $\mathrm{MSW}=$ municipal solid waste, $\mathrm{TBS}=$ transportation blend stock . 


\section{Acidic or Enzymatic Pretreatment of Cellulosic Feedstocks with Fermentative Upgrading}

The majority (see Table 2) of the U.S. (89\%) and international (85\%) projects involve A/E pretreatment and fermentation of cellulosic biomass. The majority of these projects use corn kernel cellulose or crop residues as feedstocks. These projects are covered separately below due to the differences in the technologies for conversion. All anticipated operational start dates described below for this technology represent forward-looking projections from the survey, which will be updated in future studies after these projects become operational.

In the U.S., many projects are pursuing innovative routes for cellulosic ethanol production through the addition of new conversion technologies. Several conversion technologies are being developed that could be integrated into existing corn grain ethanol dry mill biorefineries for the production of cellulosic ethanol from corn kernel cellulosic fibers. Two major conversion technologies operating in biorefineries in 2016 include ICM's ACE + Enogen and Edeniq's Cellunator + enzymes technologies. ICM's technology (i.e., ACE + Enogen) separates the corn kernel cellulosic fibers for a pretreatment, fermentation, and distillation process that takes place in parallel with corn ethanol distillation (ICM, Inc. 2016). The ICM technology can increase cellulosic yields to up to $7 \%-10 \%$ of existing corn ethanol production. Edeniq's technology (i.e., Cellunator) and licensed enzymes are used for corn kernel cellulosic fiber mixing, milling, and fermentation with the corn grain slurry (Edeniq 2016a). The Edeniq technology can increase cellulosic yields up to $2.5 \%$ of existing corn ethanol production and a $7 \%$ increase in overall ethanol yield. If ICM and Edeniq technology were implemented industry wide in the U.S., around 300 to 1,500 MMGY ( $2 \%-10 \%$ of capacity) of cellulosic ethanol capacity would be available given the operating capacity of 15,100 MMGY in 2015 (RFA 2016). In this report, corn kernel cellulosic projects are listed separately from other projects using crop residues because the technology for the conversion of corn kernel cellulose is integrated into the existing corn grain ethanol plant.

Three commercial facilities are currently producing cellulosic ethanol biochemically from corn kernel cellulose. Quad County Corn Processors operates a 35-MMGY corn ethanol plant that in 2014 installed the ICM technology to produce 2.1 MMGY of cellulosic ethanol (Johnson 2015). Flint Hills in Shell Rock, Iowa, operates a 120-MMGY corn ethanol plant that in 2016 installed the Edeniq technology to produce 3 MMGY of cellulosic ethanol (Sapp 2016a). Pacific Ethanol operates a 60-MMGY corn ethanol plant that in 2015 installed Edeniq's technology to produce 1.5 MMGY of cellulosic ethanol (Pacific Ethanol 2016).

Another five U.S. projects (three Flint Hills Resources facilities [8.5 MMGY], Mid-American Agri Products-Wheatland [MAAPW] LLC [1.1 MMGY], and Siouxland Energy [1.5 MMGY]) were identified as working on installing the Edeniq technology and licensing enzymes to begin operations in 2017 (Edeniq 2016b; Edeniq 2016c; Jessen 2016). Three U.S. projects (Redfield Energy [3.4 MMGY], E Energy Adams [3 MMGY] and Kansas Ethanol [3.6 MMGY]) were identified as working on installing the ICM technology to begin operations in 2017 (ICM, Inc. 2015). In Canada, IGPC Ethanol is working on installing ICM technology to begin operations in 2017 (ICM, Inc. 2015).

At the end of 2016, eight pioneer commercial-scale facilities were operating to produce cellulosic ethanol from crop residues, with two projects in the U.S., two projects in Brazil, three 
projects in China, and one project in Italy. The total U.S. and international operating capacity is 55 and 79 MMGY, respectively. POET-DSM broke ground in 2012 in Iowa on a 25-MMGY facility, began operating in commissioning and start-up in 2014, and is expected to begin producing cellulosic ethanol continuously from corn stover in 2017 (POET-DSM 2016). DuPont broke ground in 2012 in Iowa on a 30-MMGY facility, began operating in commissioning and start up in 2015, and is expected to begin producing cellulosic ethanol from corn stover by 2018. GranBio (22 MMGY) and Raízen Energia (11 MMGY) in Brazil both broke ground in 2013 and began operating and producing cellulosic ethanol from sugarcane bagasse and straw, respectively, in 2014 (Beta Renewables 2016a; Iogen 2016). Beta Renewables in Italy broke ground in 2011 on a 13-MMGY facility and began operating and producing cellulosic ethanol, primarily from wheat straw, in 2013. Henan Tianguan Group's two facilities (3.3 and 10 MMGY) in China began producing cellulosic ethanol from corn stover and wheat straw in 2009 and 2011. ShanDong Longlive in China began operating a 20-MMGY plant for producing cellulosic ethanol from corn stover.

At the end of 2016, two commercial-scale facilities were under construction to produce cellulosic ethanol. The total U.S. and international under-construction capacity is 6 and $18 \mathrm{MMGY}$. Fiberight broke ground in 2016 in Maine on its 6-MMGY cellulosic ethanol from municipal solid waste (MSW) plant and the facility is expected to begin operations in 2018 (Sapp 2016b). Beta Renewables broke ground in 2016 in Slovakia for an 18-MMGY facility for producing cellulosic ethanol from wheat straw and corn stover, with operations expected to begin in 2018 (Beta Renewables 2016b).

At the end of 2016, four commercial-scale facilities are in planning stages and one facility is planning to expand cellulosic ethanol production, with two U.S. projects and three projects in China. The total U.S. and international planned capacity is 42 and 97 MMGY, respectively. ZeaChem is planning a facility in Oregon for $22 \mathrm{MMGY}$ of cellulosic ethanol and bioproducts from wood and the facility is expected to begin operations in 2018 (ZeaChem 2016). Beta Renewables is planning a facility in North Carolina for $20 \mathrm{MMGY}$ cellulosic ethanol from energy grasses and the facility is expected to begin operations in 2018 (Beta Renewables 2016c). Beta Renewables is planning on facilities in China for $30 \mathrm{MMGY}$ for producing cellulosic ethanol from wheat straw and corn stover, with operations expected to begin in 2018 (Beta Renewables 2016d). COFCO Zhaodong Co. is planning a facility in China for $12 \mathrm{MMGY}$ of cellulosic ethanol from energy crops and is expected to begin operations in 2018. Henan Tianguan Group's 14-MMGY facility has a planned expansion of 50 MMGY for 2018.

At the end of 2016, Abengoa's 25-MMGY idle facility was sold off to Synata Bio, Inc. (Neeley 2016). Abengoa began construction in 2011 in Kansas on the 25-MMGY facility, began operating in commissioning and start-up in 2014, but idled the plant in 2015 due to insolvency of the parent company (Lane 2015a).

\section{Gasification of Cellulosic Feedstocks with either Catalytic Upgrading or Fermentative Upgrading of Syngas}

Eleven percent of U.S. projects and 15\% of international projects involve gasification. One U.S. project using gasification deconstruction and fermentation upgrading is INEOS New Planet BioEnergy. INEOS began construction in 2011 in Florida on an 8-MMGY facility for producing cellulosic ethanol from MSW. The facility began operating in commissioning and startup in 
2012, the plant was shut down several times from 2012-2015 for maintenance and upgrades, and then in 2016 the plant was shuttered for potential sale (Voegele 2016). All U.S. and international projects using a gasification deconstructions process and catalytic upgrading to fuels belong to Enerkem. Enerkem broke ground in 2012 in Canada on its first 100-MMGY facility, began operating in commissioning and startup in 2014, began producing cellulosic methanol from MSW in 2015, and is expected to produce cellulosic ethanol in 2017. Enerkem has two similar projects in the planning stages, one in Canada, and one at a site in Mississippi, USA.

\subsection{Status of Pre-Commercial Non-Starch Alcohol Biorefineries in the U.S.}

Figure 2 summarizes pre-commercial (pilot- and demonstration-scale) non-starch alcohol projects identified during this survey. In 2016 in the U.S., six demonstration and nine pilot projects were operating. No projects were identified as being in the planning or construction phases. Compared to commercial projects, current data availability for these pre-commercial projects is more limited. 


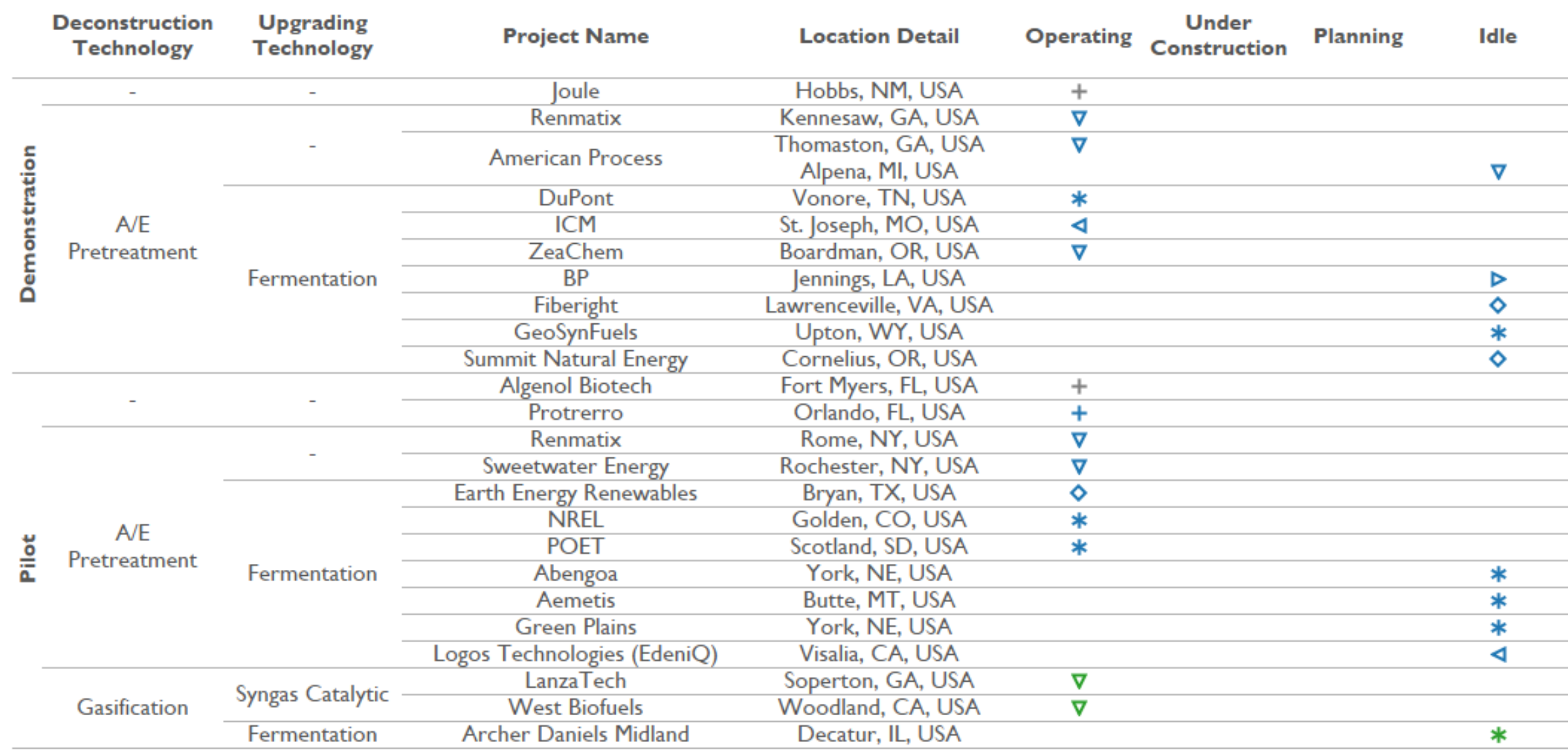

Intermediate Product

Feedstock Category

+ Algae (PBR) $\diamond M S W$

N/A
Sugars

$\triangleleft$ Corn Kernel Cellulose $\quad \boldsymbol{\nabla}$ Woody Biomass

Syngas

* Crop Residues

$\triangleright$ Dedicated Energy Crops

Figure 2. Characteristics of pilot- and demonstration-scale non-starch alcohol projects in the U.S. at the end of 2016

$\mathrm{A} / \mathrm{E}=\mathrm{acid} / \mathrm{enzymatic}, \mathrm{MSW}=$ municipal solid waste, $\mathrm{PBR}=$ photobioreactor . 
Table 3 summarizes the U.S. demonstration-scale and pilot-scale non-starch alcohol projects from this survey. The majority of the demonstration (64\%) and pilot (54\%) projects involve $\mathrm{A} / \mathrm{E}$ pretreatment and fermentation with the remainder employing technologies that use gasification followed by catalytic upgrading, fermentation upgrading, or the use of algae.

Table 3 also shows that the majority of U.S. demonstration- and pilot-scale projects are using herbaceous (i.e., corn stover and dedicated energy crops) for $\mathrm{A} / \mathrm{E}$ pretreatment and fermentation projects: $57 \%$ of U.S. projects use herbaceous feedstocks, $29 \%$ of the projects use wood-based (i.e., MSW or woody biomass) feedstocks, and 14\% of the projects use corn kernel cellulose. All $\mathrm{A} / \mathrm{E}$ pretreatment to cellulosic sugar projects are using woody biomass, all the gasification projects are using a wood-based biomass feedstock, and there are three projects for producing non-starch alcohol from algae.

Table 3. Pre-Commercial Non-Starch Alcohol Projects in 2016 by Technology and Feedstock Category

\begin{tabular}{|c|c|c|c|c|c|c|c|c|c|}
\hline \multicolumn{2}{|c|}{ Technology } & \multirow[t]{2}{*}{ Scale } & \multirow[t]{2}{*}{$\begin{array}{l}\text { Algae } \\
\text { (PBR) }\end{array}$} & \multirow{2}{*}{$\begin{array}{l}\text { Corn } \\
\text { Kernel } \\
\text { Cellulose }\end{array}$} & \multirow[t]{2}{*}{$\begin{array}{c}\text { Crop } \\
\text { Residues }\end{array}$} & \multirow{2}{*}{$\begin{array}{c}\text { Dedicated } \\
\text { Energy } \\
\text { Crops }\end{array}$} & \multirow[t]{2}{*}{ MSW } & \multirow[t]{2}{*}{$\begin{array}{l}\text { Woody } \\
\text { Biomass }\end{array}$} & \multirow[t]{2}{*}{ Total } \\
\hline $\begin{array}{l}\text { Decon- } \\
\text { struction }\end{array}$ & Upgrading & & & & & & & & \\
\hline- & - & Demo & $\mathrm{I}(\mathrm{I})$ & & & & & & $I(I)$ \\
\hline $\begin{array}{c}\text { A/E } \\
\text { Pretreatment }\end{array}$ & - & Demo & & & & & & $3(2)$ & $3(2)$ \\
\hline $\begin{array}{c}\text { A/E } \\
\text { Pretreatment }\end{array}$ & Fermentation & Demo & & $I(I)$ & $2(1)$ & $I(0)$ & $2(0)$ & $I(1)$ & $7(3)$ \\
\hline Gasification & $\begin{array}{l}\text { Syngas } \\
\text { Catalytic }\end{array}$ & Demo & & & & & & & 0 \\
\hline Gasification & Fermentation & Demo & & & & & & & 0 \\
\hline \multicolumn{2}{|c|}{ Total Demonstration } & & I (I) & I (I) & $2(1)$ & I (0) & $2(0)$ & $4(3)$ & II (6) \\
\hline- & - & Pilot & $2(2)$ & & & & & & $2(2)$ \\
\hline $\begin{array}{c}\mathrm{A} / \mathrm{E} \\
\text { Pretreatment }\end{array}$ & - & Pilot & & & & & & $2(2)$ & $2(2)$ \\
\hline $\begin{array}{c}\mathrm{A} / \mathrm{E} \\
\text { Pretreatment }\end{array}$ & Fermentation & Pilot & & I (0) & $5(2)$ & & I (I) & & $7(3)$ \\
\hline Gasification & $\begin{array}{l}\text { Syngas } \\
\text { Catalytic }\end{array}$ & Pilot & & & & & & $2(2)$ & $2(2)$ \\
\hline Gasification & Fermentation & Pilot & & & I (0) & & & & $\mathrm{I}(0)$ \\
\hline \multicolumn{3}{|c|}{ Total Pilot } & $2(2)$ & I (0) & $6(2)$ & 0 & I ( ( ) & $3(4)$ & $14(9)$ \\
\hline \multicolumn{3}{|c|}{ Grand Total } & $3(3)$ & $2(1)$ & $8(3)$ & I (0) & $3(1)$ & $8(7)$ & 25 (15) \\
\hline
\end{tabular}

Operating projects are in ( ). A/E = acid/enzymatic, $M S W=$ municipal solid waste, $P B R=$ photobioreactor

\subsection{Status of Commercial Renewable Hydrocarbon Biorefineries}

In the U.S., about 500 million gallons of hydrocarbons from fats, oils, and greases (FOG) were supplied (includes production and imports) in 2014, about 530 million gallons of hydrocarbons from FOG were supplied in 2015, and as of December 2016, about 550 million gallons of hydrocarbons from FOG were supplied in that year (EPA 2016). In the U.S. in 2014, only around 5,000 gallons of hydrocarbons from cellulose were supplied; around 0.28 million gallons of hydrocarbons from cellulose were produced in 2015, and as of November 2016, 0.53 million gallons of hydrocarbons from cellulose were produced that year (EPA 2016). 
Figure 3 summarizes the U.S. and international commercial-scale renewable hydrocarbon projects identified for this survey. ${ }^{2}$ Table 4 summarizes the U.S. and international commercial renewable hydrocarbon projects from this survey. Most U.S. and international projects are using catalytic upgrading of FOG. Most of the remaining U.S. and international projects are producing renewable hydrocarbons from wood using thermochemical processes: i.e., gasification and catalytic upgrading through the catalytic upgrading of syngas, pyrolysis and catalytic upgrading of oils, and pyrolysis to pyrolysis oil for use as heating oil or as feedstock into a petroleum refinery.

Table 4. Commercial Renewable Hydrocarbon Projects in 2016 by Technology and Feedstock Category

\begin{tabular}{|c|c|c|c|c|c|c|}
\hline \multicolumn{2}{|c|}{ Technology } & \multirow[t]{2}{*}{ Region } & \multirow[t]{2}{*}{ Algae } & \multirow[t]{2}{*}{ FOGMSW } & \multicolumn{2}{|c|}{$\begin{array}{l}\text { Woody } \\
\text { Biomass }\end{array}$} \\
\hline Deconstruction & Upgrading & & & & & \\
\hline- & - & U.S. & & & & 0 \\
\hline- & Oil Catalytic & U.S. & & $9(4)$ & & $9(4)$ \\
\hline Gasification & Syngas Catalytic & U.S & & I (0) & $2(0)$ & $3(0)$ \\
\hline Pyrolysis & - & U.S. & & & I (0) & I (0) \\
\hline Pyrolysis & Oil Catalytic & U.S. & & & $\mathrm{I}(0)$ & $\mathrm{I}(0)$ \\
\hline & U.S. Total & & 0 & $9(4)$ I (0) & $4(0)$ & $14(4)$ \\
\hline - & - & International & $\mathrm{I}(\mathrm{I})$ & & & I (I) \\
\hline- & Oil Catalytic & International & & $\begin{array}{l}11 \\
(10)\end{array}$ & & II (I0) \\
\hline Gasification & Syngas Catalytic & International & & & I (0) & I (0) \\
\hline Pyrolysis & - & International & & & $5(3)$ & $5(3)$ \\
\hline Pyrolysis & Oil Catalytic & International & & & & 0 \\
\hline & rnational Total & & I (I) & $\begin{array}{l}\text { II } \\
(10)\end{array}$ & $6(3)$ & $18(14)$ \\
\hline & & Grand Total & $I(I)$ & $\begin{array}{c}20 \\
(14)\end{array}$ & $10(3)$ & $32(18)$ \\
\hline
\end{tabular}

Operating projects are in ( ). FOG = fats, oils, and greases and MSW = municipal solid waste.

${ }^{2}$ This survey may not have fully identified all renewable hydrocarbon production capacity due to the lack of reporting on petroleum refineries that installed technology to co-process FOG with crude oil. 


\begin{tabular}{|c|c|c|c|c|c|c|c|c|c|c|}
\hline & $\begin{array}{l}\text { Deconstruction } \\
\text { Technology }\end{array}$ & $\begin{array}{l}\text { Upgrading } \\
\text { Technology }\end{array}$ & Project Name & Location Detail & $\begin{array}{c}\text { Anticipate } \\
\text { Product/Market }\end{array}$ & $\begin{array}{c}\text { Commercial } \\
\text { Capacity } \\
\text { (MMGY) }\end{array}$ & Operating & $\begin{array}{c}\text { Under } \\
\text { Construction }\end{array}$ & Planning & Idle \\
\hline \multirow{13}{*}{ نִ } & \multirow{8}{*}{ - } & \multirow{8}{*}{ Oil Catalytic } & AltAir Fuels & Los Angeles, CA, USA & TBS & 42 & $\Delta$ & & & \\
\hline & & & Cetane Energy & Carlsbad, NM, USA & TBS & 3 & $\Delta$ & & & \\
\hline & & & Renewable Energy Group & Geismar, LA, USA & TBS & 75 & $\Delta$ & & & \\
\hline & & & Diamond Green Diesel & Norco, LA, USA & TBS & $\begin{array}{l}160 \\
115\end{array}$ & $\Delta$ & $\Delta$ & & \\
\hline & & & East Kansas Agri-Energy & Garnett, KS, USA & TBS & 3 & & $\Delta$ & & \\
\hline & & & Emerald Biofuels & Plaquemine, LA, USA & TBS & 88 & & & $\Delta$ & \\
\hline & & & SG Preston & South Point, OH, USA & TBS & 120 & & & $\Delta$ & \\
\hline & & & Green Energy Products & Wichita, KS, USA & TBS & 3 & & & & $\Delta$ \\
\hline & \multirow{3}{*}{ Gasification } & \multirow{3}{*}{ Syngas Catalytic } & Fulcrum BioEnergy & Reno, NV, USA & TBS & 10 & & & $\diamond$ & \\
\hline & & & Red Rock Biofuels & Lakeview, OR, USA & TBS & 15.5 & & & $\nabla$ & \\
\hline & & & Sundrop Fuels & Boyce, LA, USA & TBS & 200 & & & $\boldsymbol{\nabla}$ & \\
\hline & & - & Ensyn & Vienna, Georgia, USA & refinery feedstock & 20 & & & $\nabla$ & \\
\hline & Pyrolysis & Oil Catalytic & $\mathrm{KiOR}$ & Columbus, MS, USA & TBS & 13 & & & & $\nabla^{*}$ \\
\hline \multirow{17}{*}{ 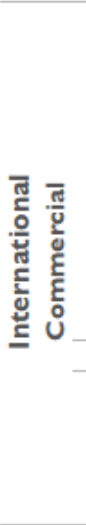 } & \multirow{11}{*}{ Cif } & \multirow{11}{*}{ Oil Catalytic } & Solazyme & Moema, Brazil & TBS/bioproducts & 2.7 & 0 & & & \\
\hline & & & \multirow{6}{*}{ Neste Oil } & Gibraltar-San Roque, Spain & TBS & 12 & $\Delta$ & & & \\
\hline & & & & La Rabida, Spain & TBS & 12 & $\Delta$ & & & \\
\hline & & & & Port Marghera, Italy & TBS & 170 & $\Delta$ & & & \\
\hline & & & & Porvoo, Finland & TBS & 63 & $\Delta-\times 2$ & & & \\
\hline & & & & Rotterdam, Netherlands & TBS & 275 & $\Delta$ & & & \\
\hline & & & & Singapore, Singapore & TBS & 275 & $\Delta$ & & & \\
\hline & & & Preem & Gothenburg, Sweden & TBS & 4.1 & $\Delta$ & & & \\
\hline & & & Repsol & Cartagena, Spain & TBS & 14 & $\Delta$ & & & \\
\hline & & & UPM Biofuels & Lappeenranta, Finland & TBS & 32 & $\Delta$ & & & \\
\hline & & & La Mède & Châteauneuf-les-Martigues, France & TBS & 24 & & $\Delta$ & & \\
\hline & Gasification & Syngas Catalytic & Total & Dunkirk, France & TBS & 72 & & $\boldsymbol{\nabla}$ & & \\
\hline & \multirow{5}{*}{ Pyrolysis } & \multirow[t]{5}{*}{ 20. } & BTG & Hengelo, Netherlands & refinery feedstock & 5.3 & $\nabla$ & & & \\
\hline & & & Fortum & Joensuu, Finland & heating oil & II & $\nabla$ & & & \\
\hline & & & \multirow{3}{*}{ Ensyn } & Renfrew, Canada & heating oil & 3 & $\nabla$ & & & \\
\hline & & & & Cote Nord, Canada & refinery feedstock & 10 & & $\nabla$ & & \\
\hline & & & & Aracruz, Brazil & refinery feedstock & 20 & & & $\nabla$ & \\
\hline
\end{tabular}

Intermediate Product

Oils

Pyrolysis Oils

Syngas

\section{Feedstock Category}

O Algae

$\triangle$ FOG

$\diamond M S W$ $\boldsymbol{\nabla}$ Woody Biomass

Figure 3. Characteristics of U.S. and international commercial renewable hydrocarbon projects at the end of 2016

FOG = fats, oils, and greases, MMGY = million gallons per year, MSW = municipal solid waste, $\mathrm{TBS}=$ transportation blend stock .

*The KiOR biorefinery equipment was bought by Renewable Energy Group Inc. in 2016. Renewable Energy Group does not intend to restart the plant. 


\section{Catalytic Upgrading of Fats, Oils, and Greases}

Hydrotreating of FOG (from crops or wastes) is an alternative process to biodiesel (i.e., esterification) for producing biomass-based diesel fuels. Hydrotreated products are also called renewable diesel fuels in the U.S. and can be used in vehicles without engine modifications and can utilize existing petroleum distribution systems. The majority (see Table 4) of the U.S. (64\%) and international (61\%) projects involve catalytic upgrading of FOG from crops or waste sources. All anticipated operational start dates described below for this technology represent forward-looking projections from the survey, which will be updated in future studies after these projects become operational.

At the end of 2016, 14 commercial-scale facilities were operating to produce renewable hydrocarbons from FOG, with five projects in the U.S., three projects in Finland, one project in Singapore, one project in Sweden, three projects in Spain, and one project in Italy. The total U.S. operating capacity is $280 \mathrm{MMGY}$. AltAir Fuels retrofitted an existing petroleum refinery in 2014 in California for a 42-MMGY facility to primarily produce jet fuel and began operating late 2015 (Lane 2016). Diamond Green Diesel broke ground in 2011 in Louisiana for a 160-MMGY facility to primarily produce diesel fuel and began operating in 2014 (Diamond Green Diesel 2016). Dynamic Fuels broke ground in 2008 in Louisiana for a 75-MMGY facility to primarily produce diesel fuel and began operating in 2010 in commissioning phase; however, the facility was idled in 2013 before being acquired by Renewable Energy Group, Inc. in 2014 (Business Wire 2014). Renewable Energy Group, Inc. was in the process of startup in early 2015 before idling due to a fire and resumed operations in 2016 (AP 2015; REG 2016). Cetane Energy retrofitted an existing biodiesel refinery in 2009 in Louisiana for a 3-MMGY facility to primarily produce diesel fuel and began operating in 2010 (Cetane Energy 2016).

The total international operating capacity is 770 MMGY. Neste Oil is the world's leading producer of renewable diesel with three refineries (in Finland, the Netherlands, and Singapore) with a combined operating capacity of about 675 MMGY (CARB 2015). Neste Oil began operating its first 63-MMGY plant in 2007 in Finland with a 63-MMGY expansion of capacity in 2009; the 280-MMGY Singapore facility began operating in 2010 and the 280-MMGY Netherlands facility began operating in 2011. Eni began converting one of its existing petroleum refining facilities in 2013 in Italy for a 170-MMGY facility to primarily produce diesel fuel and began operating in 2014 (Eni 2016). Cepsa added capacity (24 MMGY total) to co-produce renewable diesel at two petroleum refining facilities in 2009 in Spain and began operating in 2011 (USDA 2013). Repsol added capacity (14 MMGY) to co-produce renewable diesel at one petroleum refining facility in 2010 in Spain and began operating in 2012 (USDA 2013). At existing pulp and paper mills, Preem in Sweden and UPM Biofuels in Finland began construction of facilities to primarily produce biofuels from tall oil derived from woody material and began operating in 2015. Preem began construction in 2008 for a 4.1-MMGY facility to begin producing diesel in 2010 and UPM Biofuels began construction in 2012 for a 32-MMGY facility to begin producing diesel and jet fuel in 2015 (IEA 2016; UPM Biofuels 2016).

At the end of 2016, four commercial-scale facilities were under construction to produce renewable hydrocarbons from FOG, with three U.S. projects and one project in France. The total U.S. and international under-construction capacity is 120 and 24 MMGY, respectively. In 2016, Diamond Green Diesel began expansion of its existing Louisiana facility to an additional 115 MMGY for a total of about 280 MMGY (Diamond Green Diesel 2016). At an existing corn ethanol facility, East Kansas Agri-Energy began construction in 2011 in Kansas for a 3-MMGY 
facility to primarily produce diesel fuel from corn oil and is expected to begin operations in 2017 (East Kansas Agri-Energy 2016). In France, Total began retrofitting the existing La Mède petroleum refinery in 2015 for $24 \mathrm{MMGY}$ of diesel production and the facility is expected to begin operations in 2017 (Total 2016).

At the end of 2016, two commercial-scale facilities are in the planning stages to produce renewable hydrocarbons from FOG in the U.S. The total U.S. planned capacity is 210 MMGY. Emerald Diesel is planning a facility in Louisiana for $88 \mathrm{MMGY}$ of renewable diesel, and the facility is expected to begin operations in 2019. SG Preston is planning a facility in Ohio for 120 MMGY of renewable diesel and jet fuel and the facility is expected to begin operations in 2020 (SG Preston 2016).

In the U.S., Green Energy Products began producing renewable diesel in 2015 from a 3-MMGY commercial-scale facility in Kansas from corn oil, but the facility was idled in 2016, likely due to a fire at the co-located biodiesel facility in 2013 and the subsequent parent company bankruptcy (Voorhis 2016).

\section{Gasification of Cellulosic Feedstocks and Catalytic Upgrading of Syngas}

At the end of 2016, one commercial-scale facility is under construction to produce renewable hydrocarbons from woody forest residues or dedicated energy crops in France (IEA 2016). In 2016, Total began repurposing an existing petroleum refinery for a 72-MMGY facility with plans to begin operating in 2017 (IEA 2016).

At the end of 2016, three commercial-scale facilities were planned in the U.S. to produce renewable hydrocarbons from wood. The total U.S. planned capacity is 230-MMGY. Fulcrum BioEnergy in Nevada and Red Rock Biofuels in Oregon are planning on converting MSW and woody biomass, respectively. Both expected to break ground on construction in 2017 and begin operating to produce primarily jet fuel in 2019 (Red Rock Biofuels 2016; Fulcrum BioEnergy 2016). Fulcrum completed construction of an MSW sorting facility at the Nevada site in 2016 (Conway 2016). Sundrop Fuels plans to operate a 200-MMGY facility for the conversion of woody biomass in 2020 in Louisiana (Sundrop Fuels 2016).

\section{Pyrolysis of Cellulosic Feedstocks and Catalytic Upgrading of Oils}

At the end of 2016, three commercial-scale facilities are operating to produce renewable hydrocarbons from woody biomass, with a project each in Finland, the Netherlands, and Canada. The total international operating capacity is 19 MMGY. In 2015, BTG began operating a 5.3MMGY facility in the Netherlands to produce stabilized pyrolysis oil for feeding into a petroleum refinery. In 2014, Ensyn and Fortum began operating 3-MMGY and 11-MMGY facilities in Canada and Finland, respectively, to produce stabilized pyrolysis oil for heating oil.

At the end of 2016, one commercial-scale facility was under construction in Canada to produce renewable hydrocarbons from wood through pyrolysis for stable pyrolysis oil that can serve as a feedstock to a petroleum refinery. The total international under-construction capacity is 230 MMGY. In 2016, Ensyn broke ground at Cote Nord on a 10-MMGY facility with plans to begin operating in 2017. At the end of 2016, two 20-MMGY commercial facilities were planned in the U.S. and Brazil to produce renewable hydrocarbons from wood. Both facilities are intended to be operating in 2019. 
In the U.S., KiOR began producing renewable diesel in 2013 from a 13-MMGY facility in Mississippi that used pyrolysis and catalytic oil upgrading, but the facility was idled in 2014 (Mississippi Business Journal 2014). In 2015, the KiOR facility was sold to Renewable Energy Group for the equipment, and the company has no plans to run the facility (Lane 2015b).

\section{Algae Technologies for Producing Oils}

At the end of 2016, one commercial-scale facility in Brazil was producing algal oils. Solazyme broke ground in 2012 in Brazil for a 2.7-MMGY facility to produce oils from algae for either the production of jet fuel or bioproducts and began operating in 2015 (Solazyme 2016).

\subsection{Status of Pre-Commercial Renewable Hydrocarbon Biorefineries in the U.S.}

Figure 4 summarizes U.S. demonstration- and pilot-scale renewable hydrocarbon projects identified during this survey. Table 5 summarizes the demonstration and pilot renewable hydrocarbon projects. Table 25 also summarizes the technology and feedstock categories used in each project. In the U.S. in 2016, five demonstration and 15 pilot projects were operating with one demonstration and one pilot project scheduled to become operational sometime after the end of 2016. No pilot projects are under construction. Sixty percent of the demonstration and pilot projects use MSW or woody biomass, 20\% use algae, 10\% use cellulosic sugars, 7.5\% use FOG, and $2.5 \%$ use crop residues. Compared to commercial-scale projects, current data availability for these pre-commercial projects is more limited. 
Table 5. U.S. Demonstration- and Pilot-Scale Renewable Hydrocarbon Projects in 2016 by Technology and Feedstock Category

\begin{tabular}{|c|c|c|c|c|c|c|c|c|}
\hline \multicolumn{2}{|c|}{ Technology } & \multirow[t]{2}{*}{ Region } & \multirow[t]{2}{*}{ Algae } & \multirow[t]{2}{*}{$\begin{array}{c}\text { Cellulosic } \\
\text { Sugars }\end{array}$} & \multirow[t]{2}{*}{$\begin{array}{c}\text { Crop } \\
\text { Residues }\end{array}$} & \multirow[t]{2}{*}{ FOGMSW } & \multirow[t]{2}{*}{$\begin{array}{l}\text { Woody } \\
\text { Biomass }\end{array}$} & \multirow[t]{2}{*}{ Total } \\
\hline $\begin{array}{l}\text { Decon- } \\
\text { struction }\end{array}$ & Upgrading & & & & & & & \\
\hline- & - & Demo & I (I) & & & & & I (0) \\
\hline- & Fermentation & Demo & & $2(1)$ & & & & $2(1)$ \\
\hline- & Oil Catalytic & Demo & I (0) & & & I (I) & & $2(I)$ \\
\hline $\begin{array}{c}\text { A/E } \\
\text { Pretreatment }\end{array}$ & Sugar Catalytic & Demo & & I (I) & & & & I (I) \\
\hline $\begin{array}{c}\mathrm{A} / \mathrm{E} \\
\text { Pretreatment }\end{array}$ & Oil Catalytic & Demo & & & & & & 0 \\
\hline Gasification & Syngas Catalytic & Demo & & & & I (0) $3(0)$ & & $4(0)$ \\
\hline HTL & Oil Catalytic & Demo & & & & & & 0 \\
\hline Pyrolysis & - & Demo & & & & & & 0 \\
\hline Pyrolysis & Oil Catalytic & Demo & & & & & $3(2)$ & $3(2)$ \\
\hline \multicolumn{2}{|c|}{ Demonstration Total } & & $2(1)$ & $3(2)$ & 0 & $2(I) 3(0)$ & $3(2)$ & $13(6)$ \\
\hline- & - & Pilot & I (I) & & & & & I (0) \\
\hline- & Fermentation & Pilot & & I (0) & & & & I (0) \\
\hline- & Oil Catalytic & Pilot & $2(0)$ & & & I (I) & & $3(1)$ \\
\hline $\begin{array}{c}\text { A/E } \\
\text { Pretreatment }\end{array}$ & Sugar Catalytic & Pilot & & & & & & 0 \\
\hline $\begin{array}{c}\text { A/E } \\
\text { Pretreatment }\end{array}$ & Oil Catalytic & Pilot & & & $\mathrm{I}(0)$ & & & $\mathrm{I}(0)$ \\
\hline Gasification & Syngas Catalytic & Pilot & & & & $2(2)$ & $4(2)$ & $6(4)$ \\
\hline HTL & Oil Catalytic & Pilot & I (I) & & & & I (I) & $2(2)$ \\
\hline Pyrolysis & - & Pilot & & & & $2(1)$ & $2(2)$ & $4(3)$ \\
\hline Pyrolysis & Oil Catalytic & Pilot & $2(0)$ & & & & $7(5)$ & $9(5)$ \\
\hline \multirow{2}{*}{\multicolumn{2}{|c|}{ Pilot Total }} & & $6(2)$ & I (0) & I (0) & I (I) 4 (3) & $14(10)$ & $26(16)$ \\
\hline & & id Total & $8(2)$ & $4(2)$ & I (0) & $3(2) 7(3)$ & $17(12)$ & $40(2 I)$ \\
\hline
\end{tabular}

Operating projects are in $($ ). FOG $=$ fats, oils, and greases; $\mathrm{HTL}=$ hydrothermal liquefaction, and MSW $=$ municipal solid waste. 


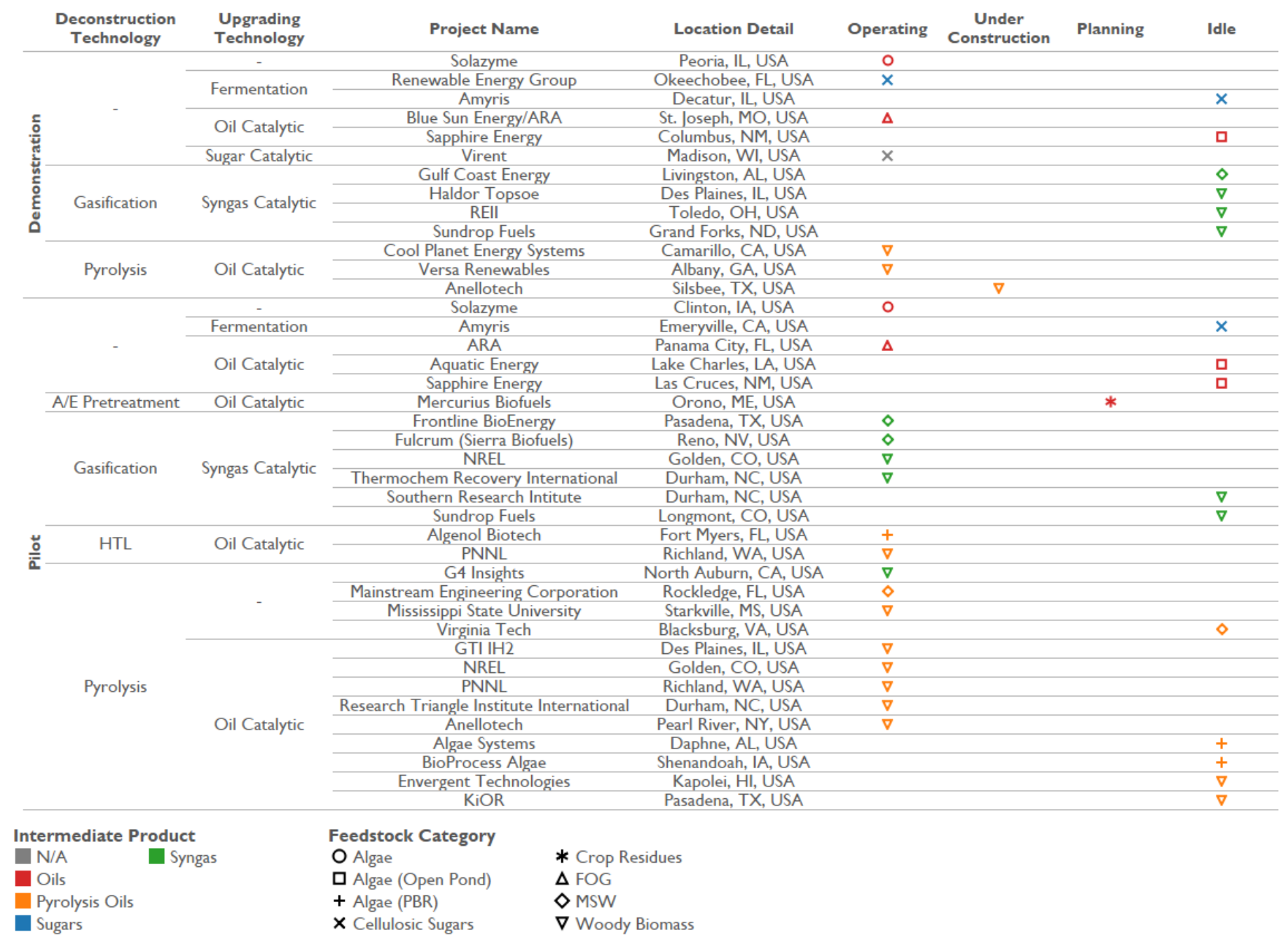

Figure 4. Characteristics of U.S. demonstration- and pilot-scale renewable hydrocarbon projects at the end of 2016

FOG = fats, oils, and greases, $\mathrm{HTL}=$ hydrothermal liquefaction, $\mathrm{MMGY}=$ million gallons per year, $\mathrm{PBR}=$ photobioreactor, $\mathrm{MSW}=$ municipal solid waste. 


\section{Future Directions}

The purpose of this report is to document the status of the non-starch alcohol and renewable hydrocarbon biofuels industry and provide perspective on the development of this industry over time. Future improvements will continue to focus on ensuring all existing and new facilities and companies are identified and expanding the type of data gathered on each facility. Future improvements could include additional analysis of commercial-scale biofuel production capacity over time as well as more robust analysis of companies that have carried out pilot, demonstration, and commercial projects. This could include more analysis of how existing capital is used for biorefineries and ramp-up and commissioning of biorefineries. We welcome feedback and suggestions and especially appreciate information from companies currently represented as well as companies that were not included in this report. 


\section{References}

Alternative Fuels Data Center (AFDC). 2016. "Emerging Alternative Fuels." http://www.afdc.energy.gov/fuels/emerging.html.

The Associated Press (AP). 2015. "Geismar Biorefinery Will Restart in January." http://www.wbrz.com/news/geismar-biorefinery-will-restart-in-january/.

Bacovsky, D.; N. Ludwiczek; M. Ognissanto; M. Wörgetter. 2013. Status of Advanced Biofuels Demonstration Facilities in 2012. T39-P1b. Paris, France: International Energy Agency.

Beta Renewables. 2016a. "Projects / GranBio."

http://www.betarenewables.com/en/projects/granbio.

_. 2016b. "Projects / Energochemica."

http://www.betarenewables.com/en/projects/energochemica.

—. 2016c. "Projects / Alpha." http://betarenewables.com/en/projects/alpha.

_. 2016d. "Projects / Fuyang Bioproject."

http://www.betarenewables.com/en/projects/fuyang-bioproject.

British Petroleum (BP). 2016. BP Statistical Review of World Energy June 2016. London: British Petroleum.

Business Wire. 2014. "Renewable Energy Group Completes Dynamic Fuels Acquisition." http://www.businesswire.com/news/home/20140609005435/en/Renewable-Energy-GroupCompletes-Dynamic-Fuels-Acquisition.

California Air Resources Board (CARB). 2015. "NExBTL Renewable Diesel Singapore Plant." https://www.arb.ca.gov/fuels/lcfs/2a2b/apps/neste-aus-rpt-031513.pdf.

Cetane Energy. 2016. "Products." http://www.cetaneenergy.com/products.html.

Conway, A. 2016. "Fulcrum Works to Convert Trash into Biofuel." North Nevada Business Weekly. http://www.nnbw.com/news/fulcrum-works-to-convert-trash-into-biofuel/.

Diamond Green Diesel. 2016. "Welcome to Diamond Green Diesel." https://www.diamondgreendiesel.com/.

East Kansas Agri-Energy. 2016. "Renewable Diesel.” http://ekaellc.com/renewable-diesel/.

Edeniq. 2016a. "Migration to Cellulosic Ethanol at Today's Ethanol Plants." http://www.edeniq.com/pathway/.

_. 2016b. "Siouxland Energy Selects Edeniq Cellunator and Pathway Technology." http://www.edeniq.com/pdf/2016_0609.pdf. 
_. 2016c. "Flint Hills Resources Licenses Edeniq's Pathway Technology." http://www.edeniq.com/pdf/2016_0210.pdf.

Eni. 2016. "Company.” https://www.eni.com/en_IT/company.page.

European Biofuels Technology Platform. 2016. "Biofuels for Air Transport." http://biofuelstp.eu/aviation-biofuels.html\#standards.

Fulcrum BioEnergy. 2016. "Sierra BioFuels Plant." http://fulcrum-bioenergy.com/facilities/.

Hart Energy. 2011. Global Biofuels Outlook 2011-2020. Houston, TX: Hart Energy Research Group.

ICM, Inc. 2015. "Kansas Ethanol to install ICM's Fiber Separation Technology.” Biofuels Digest. http://ethanolproducer.com/articles/11907/kansas-ethanol-to-install-icms-fiberseparation-technology.

- 2016. "Generation 1.5: Grain Fiber to Cellulosic Ethanol Technology." http://www.icminc.com/products/generation-1-5.html.

International Energy Agency (IEA). 2014. "IEA Bioenergy Task 42 Biorefining." Wageningen, the Netherlands: IEA. http://www.ieabioenergy.com/wp-content/uploads/2014/09/IEABioenergy-Task42-Biorefining-Brochure-SEP2014 LR.pdf .

2016: http://demoplants.bioenergy2020.eu/.

International Renewable Energy Agency (IRENA). 2016. "Innovation Outlook: Advanced Liquid Biofuels."

http://www.irena.org/menu/index.aspx?mnu=Subcat\&PriMenuID=36\&CatID=141\&SubcatID=2 $\underline{741 .}$.

Iogen Corporation. 2016. “Costa Pinto Project.” http://www.iogen.ca/raizen-project/.

Jessen, H. 2016. "Edeniq Cellunators Installed at Nebraska Ethanol Plant." Ethanol Producer Magazine. http://ethanolproducer.com/articles/13129/edeniq-cellunators-installed-at-nebraskaethanol-plant.

Johnson, D. 2015. “Quad County Corn Processors.” https://ethanol.org/Delayne\%20Johnson.pdf.

Lane, Jim. 2013. "Biofuels Digest SuperData Gold Service.” Biofuels Digest. www.biofuelsdigest.com/bdigest/biofuels-digest-superdata.

_.2015a. "Abengoa Seeks Insolvency Protection, Takes a Voyage to the Bottom of the Bond Markets." Biofuels Digest. http://www.biofuelsdigest.com/bdigest/2015/11/25/abengoaseeks-insolvency-protection-takes-a-voyage-to-the-bottom-of-the-bond-markets/. 
- 2015b. "Renewable Energy Group acquires KiOR Hydrotreater, Distillation Column, Tankers for \$1.5M.” http://www.biofuelsdigest.com/bdigest/2015/10/06/renewable-energygroup-acquires-kior-hydrotreater-distillation-column-tankers-for-1-5m/.

- 2016. "Renewable Jet Fuel, Competitive Cost, at Scale: The Digest's Multi-Slide Guide to AltAir." http://www.biofuelsdigest.com/bdigest/2016/05/19/63308/.

Mississippi Business Journal. 2014. "KiOR Shutting Down Production at Columbus Plant." http://msbusiness.com/2014/02/kior-shutting-production-columbus-plant/.

Neeley, T. 2016. “Kansas Cellulosic Plant Sells for \$48M.” The Progressive Farmer. https://www.dtnpf.com/agriculture/web/ag/news/business-inputs/article/2016/12/01/abengoacompletes-sale-us-ethanol-2.

Pacific Ethanol. 2016. "Pacific Ethanol Receives EPA-Approved Registration for Cellulosic Ethanol Production at Stockton Plant." http://ir.stockpr.com/pacificethanol/pressreleases/detail/485/pacific-ethanol-receives-epa-approved-registration-for-cellulosic-ethanolproduction-at-stockton-plant.

Peterson, S.; E. Newes; D. Inman; L. Vimmerstedt; D. Hsu; C. Peck; D. Stright; B. Bush. 2013. "An Overview of the Biomass Scenario Model." Proceedings of the 3International Conference of the System Dynamics Society, Cambridge, Massachusetts, July 21-

25.http://www.systemdynamics.org/conferences/2013/proceed/papers/P1352.pdf.

POET-DSM. 2016. "Project Liberty." http://poet-dsm.com/liberty.

PricewaterhouseCoopers, LLP. 2014. 2nd Biofuels Market Insights Survey. New York:

PricewaterhouseCoopers, LLP.

Red Rock Biofuels. 2016. “Advanced Renewable Biofuels.” http://redrockbio.com/.

Renewable Energy Group. 2016. "REG Geismar.” http://www.regfuel.com/aboutreg/locations/biorefineries/production-mode/reg-geismar-llc.

Renewable Fuel Association (RFA). 2016. "2016 Ethanol Industry Outlook." http://www.ethanolrfa.org/wp-content/uploads/2016/02/Ethanol-Industry-Outlook-2016.pdf.

Sapp, M. 2016a. "Edeniq gets EPA OK for Flint Hills Resources' Shell Rock cellulosic ethanol." Biofuels Digest. http://www.biofuelsdigest.com/bdigest/2016/12/20/edeniq-gets-epa-ok-for-flinthills-resources-shell-rock-cellulosic-ethanol/.

- 2016b. "Fiberight Breaks Ground while PERC Appeals Permits Decision." Biofuels Digest. http://www.biofuelsdigest.com/bdigest/2016/10/31/fiberight-breaks-ground-while-percappeals-permits-decision/.

Schwab, A.; E. Warner; J. Lewis. 2016. 2015 Survey of Non-Starch Ethanol and Renewable Hydrocarbon Biofuels Producers. NREL/TP- 6A10-65519. Golden, CO: National Renewable Energy Laboratory. http://www.nrel.gov/docs/fy16osti/65519.pdf. 
SG Preston. 2016. "Portfolio." http://sgpreston.com/our-portfolio.

Solazyme. 2016. "Macroalgae: Macro Solutions.” http://solazymeindustrials.com/.

Soleki, M.; A. Scodel; B. Epstein. 2014. E2 Advanced Biofuel Market Report 2014. San Francisco, CA: E2 Environmental Entrepreneurs. https://www.e2.org/ext/doc/E2AdvancedBiofuelMarketReport2014.pdf.

Sundrop Fuels. 2016. "Renewable Advanced Biofuels." http://www.sundropfuels.com/Benefits/renewable-biofuels.

Total. 2016. http://www.total.com/en/energy-expertise/projects/bioenergies/la-mede-total-firstbiorefinery.

U.S. Department of Agriculture. 2013. "Spain: Biodiesel Standing Report." https://gain.fas.usda.gov/Recent\%20GAIN\%20Publications/Biodiesel\%20Standing\%20Report Madrid Spain 11-26-2013.pdf.

—. 2016. "Table 19: EPA Second-Generation Biofuel Plant Volumes." http://www.ers.usda.gov/data-products/us-bioenergy-statistics.aspx.

U.S. Department of Energy. 2016. Bioenergy Technologies Office Multi-Year Program Plan: March 2016. Washington, DC: U.S. Department of Energy. https://www.energy.gov/sites/prod/files/2015/03/f20/mypp beto march2015.pdf .

U.S. Environmental Protection Agency. 2016. "Public Data for the Renewable Fuel Standard." Accessed December 2016: https://www.epa.gov/fuels-registration-reporting-and-compliancehelp/public-data-renewable-fuel-standard.

UPM Biofuels. 2016. "Investment in the World's First Biorefinery Producing Wood-Based Diesel." http://www.upmbiofuels.com/biofuel-production/biorefinery/Pages/Default.aspx.

Voegele, E. 2016. "Ineos Bio to sell Ethanol Business, including Vero Beach Plant.” Biomass Magazine. http://biomassmagazine.com/articles/13662/ineos-bio-to-sell-ethanol-businessincluding-vero-beach-plant.

Voorhis, D. 2016. “Wichita-Area Maker of Biodiesel Liquidates Company.” Wichita Eagle. http://www.kansas.com/news/business/agriculture/article76197512.html.

ZeaChem. 2016. "Project Development.” http://www.zeachem.com/project-development/. 


\section{Appendix A: Definitions for Stage of Facility Development}

\begin{tabular}{|l|l|}
\hline Category & Definitions \\
\hline Stage of Development & $\begin{array}{l}\text { Planning: Ground has not been broken for construction. However, one or } \\
\text { more of the following activities has occurred: a facility location has been } \\
\text { selected, project financing negotiations have started, and/or permits have } \\
\text { been applied/obtained for a specific site. }\end{array}$ \\
$\begin{array}{l}\text { Under Construction: Ground breaking at the selected site has occurred, } \\
\text { and the facility is under construction. }\end{array}$ \\
$\begin{array}{l}\text { Operating: The facility is undergoing commissioning and start-up, } \\
\text { currently producing fuel, and/or conducting development work on a regular } \\
\text { basis. }\end{array}$ \\
$\begin{array}{l}\text { Idle: The facility is no longer producing fuels but was producing at one } \\
\text { point. Possible reasons for an idle facility include unfavorable market } \\
\text { conditions, completion of a development period, or project financial } \\
\text { constraints. }\end{array}$ \\
\hline
\end{tabular}




\section{Appendix B: Definitions for Scale of Facility}

\begin{tabular}{|l|l|}
\hline Category & Definitions \\
\hline Scale of Facility & $\begin{array}{l}\text { Pilot: Small-scale facility with unit operations; primarily used for research } \\
\text { and development work, such as to verify the integrated technical } \\
\text { performance of the given suite of technologies from feedstock in through } \\
\text { product out at production capacities with at least one dry ton of feedstock } \\
\text { per day. }\end{array}$ \\
$\begin{array}{l}\text { Demonstration: Small-scale, fully integrated facility to verify performance } \\
\text { at a scale sufficient to provide engineering and operational data and } \\
\text { equipment specifications required to design a pioneer-scale facility. }\end{array}$ \\
$\begin{array}{l}\text { Commercial: Full-scale biorefineries for economical production at } \\
\text { commercial volumes on a continuous basis with a reliable feedstock supply } \\
\text { and production distribution system. Commercial includes first-of-a-kind } \\
\text { pioneer and subsequent biorefineries. }\end{array}$ \\
\hline
\end{tabular}




\section{Appendix C: Definitions for Type of Technology}

\begin{tabular}{|l|l|}
\hline Category & Definitions \\
Technology & $\begin{array}{l}\text { Acid/Enzymatic Pretreatment: Acidic or enzymatic conversion of } \\
\text { biomass carbohydrates to cellulosic sugars } \\
\text { Gasification: Incomplete combustion of biomass to produce an energy-rich } \\
\text { syngas, with some oxygen available } \\
\text { Hydrothermal liquefaction: Thermal conversion of biomass in the } \\
\text { presence of liquid water to produce a bio-oil as main fraction }\end{array}$ \\
\hline Upgrading Technology & $\begin{array}{l}\text { Fyrolysis: Application of heat to biomass, in an absence of air, so as to } \\
\text { break it down into charcoal and various tar gasses and liquids } \\
\text { fermentation }\end{array}$ \\
\hline $\begin{array}{l}\text { Syngas Catalytic: Upgrading of syngas through catalysts for synthesis to } \\
\text { produce Fischer-Tropsch liquids, jet fuel, mixed alcohol, and methane }\end{array}$ \\
$\begin{array}{l}\text { Oil Catalytic: Upgrading of oils, such as from pyrolysis, hydrothermal } \\
\text { liquefaction, or extraction from oil seed crops, by adding hydrogen to } \\
\text { saturate double bonds and remove oxygen } \\
\text { Sugar Catalytic: Upgrading of cellulosic sugars through catalytic } \\
\text { conversion of solubilized carbohydrate streams to hydrocarbon biofuels }\end{array}$ \\
\hline
\end{tabular}




\section{Appendix D: Definitions for Feedstock Category}

\begin{tabular}{|c|c|}
\hline Category & Response Selections- Definitions \\
\hline Feedstock Category & $\begin{array}{l}\text { Algae: A large, aquatic group of simple plant-like photosynthetic } \\
\text { organisms-from microscopic cyanobacteria to giant seaweed; includes } \\
\text { algae grown in an open pond or photobioreactor } \\
\text { Corn Kernel Cellulose: Fibrous cellulose remaining after corn grain } \\
\text { ethanol production in a dry mill } \\
\text { Crop Residues: Crop residues are divided into two sub-categories: } \\
\text { harvesting crop residues and processing crop residues. Harvesting crop } \\
\text { residues are materials such as leaves, stalks, and straw left on the field after } \\
\text { crop harvesting. Processing crop residues remain after the crop has been } \\
\text { processed into a primary product and include materials such as husks and } \\
\text { bagasse. } \\
\text { Dedicated Energy Crops: Dedicated energy crops are specifically grown } \\
\text { for bioenergy production and include herbaceous (e.g., switchgrass) and } \\
\text { woody (e.g., willow) resources. All instances of feedstock use in this report } \\
\text { refer to herbaceous dedicated energy crops. } \\
\text { Municipal Solid Waste (MSW): The term refers to solid wastes from } \\
\text { residential and business sources that are then converted to produce biofuels } \\
\text { and/or electricity. Yard trimmings are a subcategory of MSW and include } \\
\text { grass clippings, leaves, and tree/brush trimmings. } \\
\text { Oils, Fats, and Greases: The term includes lipid-based feedstock that has } \\
\text { historically been used to produce biodiesel, but is emerging as a feedstock } \\
\text { for renewable hydrocarbon fuels production. These include both oils } \\
\text { extracted from agricultural crops and wood, and cleaned up vegetable or } \\
\text { animal fats, oils, and greases. } \\
\text { Woody Biomass: A broad category capturing forest logging residues, mill } \\
\text { residues, and other woody waste sources }\end{array}$ \\
\hline Intermediate Products & $\begin{array}{l}\text { Cellulosic Sugars: Sugars derived from non-food biomass such as wood, } \\
\text { biomass residues, and grasses. } \\
\text { Oils: Biomass-based oils extracted from crops or from cleaning up waste } \\
\text { vegetable or animal fats, oils, and greases. } \\
\text { Pyrolysis Oils: Oils from the pyrolytic deconstruction or hydrothermal } \\
\text { liquefaction of cellulosic biomass. } \\
\text { Syngas: Gases produced as a result of gasification of cellulosic biomass. }\end{array}$ \\
\hline
\end{tabular}




\section{Appendix E: Definitions for Anticipated Product/Market}

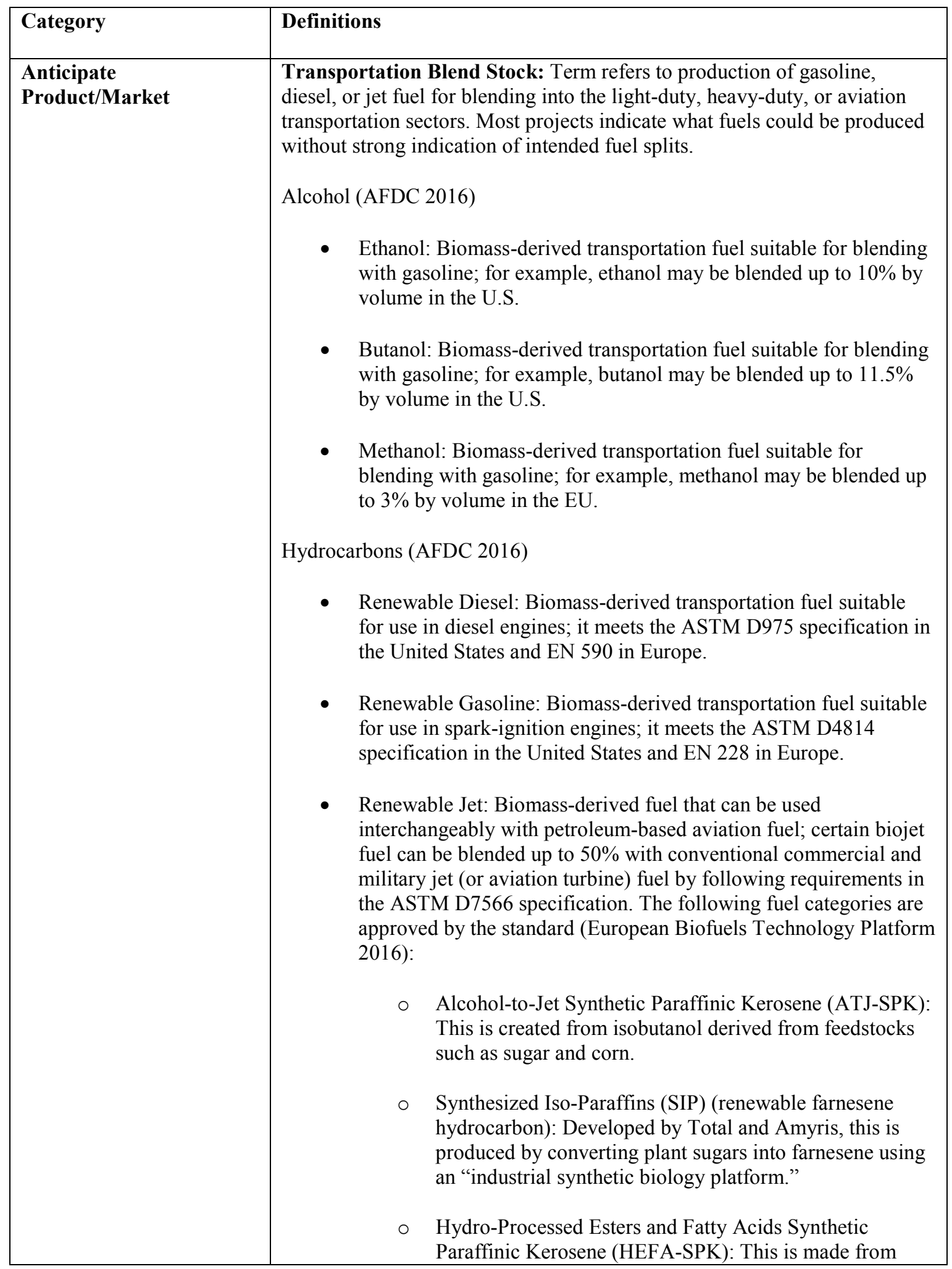




\begin{tabular}{|c|c|c|}
\hline Category & Definitions & \\
\hline & $\begin{array}{l}\text { Bioproducts: } \mathrm{P} \\
\text { derived products } \\
\text { Refinery Feeds } \\
\text { for co-processin } \\
\text { Heating Oil: } \mathrm{Pr} \\
\text { as a heating oil }\end{array}$ & $\begin{array}{l}\text { vegetable oil-containing feedstock } \\
\text { Fischer-Tropsch Synthetic Paraffinic Kerosene (FT-SPK) } \\
\text { Fischer-Tropsch Synthetic Kerosene with Aromatics (FT- } \\
\text { SKA) } \\
\text { oduction of bioproducts (for example, analogues of fossil } \\
\text { ) for use in non-fuel industry sectors } \\
\text { ock: Production of a pyrolysis oil of sufficient stabilization } \\
\text { at a petroleum refinery } \\
\text { duction of a pyrolysis oil of sufficient stabilization for use }\end{array}$ \\
\hline
\end{tabular}

